\title{
Avian IgY antibodies: characteristics and applications in immunodiagnostic
}

\author{
Anticorpos IgY aviário: características e aplicações em imunodiagnóstico
}

\author{
Lívia Silveira Munhoz ${ }^{\mathrm{I}}$ Gilberto D’Ávila Vargas ${ }^{\mathrm{I}}$ Geferson Fischer ${ }^{\mathrm{I}}$ Marcelo de Lima ${ }^{\mathrm{I}}$ \\ Paulo Augusto Esteves ${ }^{\text {II }}$ Silvia de Oliveira Hübner ${ }^{*}$
}

\section{ABSTRACT}

Immunoglobulin $Y(\operatorname{Ig} Y)$ is the major antibody isotype in birds, reptiles, amphibia, and lungfish, playing a similar biological role as mammal IgG. Due to its phylogenetic distance, immune diversification and presence in the egg yolk, IgY provide a number of advantages in immunodiagnostic compared to IgG from mammals. Moreover, IgY production is in agreement with international efforts to reduce, refine and if possible, to replace animals in experimentation, contributing substantially in favor of animal welfare. This article presents an overview about structural and functional features, production and applications of $\operatorname{IgY}$ in immunodiagnostic, as well as the advantages of chicken antibodies use.

Key words: egg yolk antibody, immunodiagnostics, immunoglobulin $Y$, polyclonal antibodies.
\end{abstract}

- REVIEW -

\section{RESUMO}

A imunoglobulina $Y(\operatorname{Ig} Y)$ é a classe de anticorpos de maior importância em aves, répteis, anfíbios e peixes pulmonados, desempenhando um papel semelhante a IgG de mamíferos. Devido a sua distância filogenética, mecanismos de diversificação imune e presença na gema do ovo, IgY proporciona uma série de vantagens em imunodiagnóstico, quando comparada a IgG de mamíferos. Além disso, esse método alternativo de produção de anticorpo está de acordo com os esforços internacionais para reduzir, refinar $e$, se possível, substituir animais em experimentação, contribuindo substancialmente a favor do bem-estar animal. Este artigo apresenta uma revisão sobre as características estruturais e funcionais da IgY, bem como os métodos de produção, vantagens e aplicações em imunodiagnóstico, além das vantagens da sua utilização.

Palavras-chave: anticorpo da gema do ovo, imunodiagnóstico, imunoglobulina $Y$, anticorpo policlonal.

\section{INTRODUCTION}

Immunoglobulins (glycoproteins also called antibody) are secreted by plasma cells in response to antigens exposure and consist in a major effector product of humoral immunity (TIZARD, 2002). These immunoglobulins are also widely used in the field of diagnostics and scientific research being employed either for detection or quantification of antibodies and specific antigens associated with various diseases by several techniques such as immunodiffusion, ELISA, and Western blotting. Historically, the animal species chosen for antibody production to be used for diagnostic purposes have been of mammalian origin. These antibodies are obtained from blood collected either by repeated bleeding or heart puncture which may frequently result in distress or even death of the animal. The production of IgY antibodies from immunized chicken eggs is an excellent alternative to the traditional methods. This review will describe the structural and functional characteristics of avian IgY, focusing on its potential as an important tool for immunodiagnosis.

\section{The IgY}

Immunoglobulin $\mathrm{Y}(\mathrm{IgY})$ is the major antibody in birds, reptiles, and lungfish (WARR et al., 1995). In birds, the IgY is found mainly in blood and in the fluid fraction of the egg providing protection to newly hatched chick (SCHADE et al., 2005).

\footnotetext{
${ }^{1}$ Laboratório de Virologia e Imunologia Animal, Departamento de Veterinária Preventiva, Universidade Federal de Pelotas (UFPel), Campus Capão do Leão, 96010-900, CP 354, Pelotas, RS, Brasil. E-mail: sohubner@yahoo.com.br. *Autor para correspondência.

"Grupo de Pesquisa em Sanidade de Aves, EMBRAPA Suínos e Aves, Vila Tamanduá, Concórdia, SC, Brasil. 
The antibodies transfer from serum to eggs was first demonstrated by KLEMPERER (1893), however this discovery remained for a long period with no scientific applications. When animal welfare became more relevant in scientific studies, researchers began to seek alternatives to reduce the indiscriminate use of animals for research and diagnostic purposes. Although IgY and IgG are sometimes used as synonyms in the scientific literature, the term IgY has become universally accepted based on its unique features (LESLIE \& CLEM, 1969; SCHADE et al., 1996; TIZARD, 2002).

\section{Structural and functional features of $\operatorname{IgY}$}

Like IgG, IgY contains two heavy and two light polypeptide chains, shaped in the Y characteristics and presents two binding sites for the antigen. IgY and IgG are eluted from diethylaminoethyl cellulose with low ionic strength buffers (WARR et al., 1995). However there are striking differences that must be considered: there is little or no immunological crossreactivity between IgY and mammalian IgG. IgY has a higher molecular weight $(\sim 180 \mathrm{kDa}$ and $\sim 160 \mathrm{kDa}$ to $\mathrm{IgG}$ ) due to an extra constant domain in its heavy chain $(\mathrm{H})$, lacks a well-defined hinge region and has an unique oligosaccharide in its structure. It has been proposed that the extra domain $(\mathrm{CH} 2)$ may be the evolutionary precursor to the mammalian IgG hinge region (WARR et al., 1995). IgY is also capable of mediate anaphylactic reactions, a function attributed to $\operatorname{IgE}$ in mammals (CARLANDER, 2002). In fact, other similarities between IgY and IgE, including a similar intra chain disulphide bond in their extra heavy chain domain, lead to suggest that $\operatorname{IgY}$ is the ancestral molecule to both $\operatorname{IgG}$ and IgE, and molecular genetic studies have confirmed these findings (WARR et al., 1995). Fc region of IgY mediates most biological effector functions, such as complement fixation, anaphylactic reactions and opsonization, whereas the Fab region contains the antigen binding sites (DAVISON et al., 2008). The $\mathrm{H}$ chain (Mw 65,105kDa) of IgY, called upsilon ("v" capital letter $\mathrm{H}$ ) has one variable (V) and four constant (C) regions whereas the light chain $(\mathrm{Mw} 18,660 \mathrm{kDa})$ is composed of one $\mathrm{V}$ and one $\mathrm{C}$ region. The light chain is lighter than its mammalian counterpart and has restricted mobility of the hinge region (Cv2) (CARLANDER, 2002). IgY is stable at $\mathrm{pH} 4-9$ and up to $65^{\circ} \mathrm{C}$ in aqueous condition. However, high salt conditions or the addition of stabilizing reagents increase its resistance to heat, acid extreme $\mathrm{pH}$ and high pressure (SHIMIZU et al., 1992).

It has been identified in some anseriform birds and reptiles the truncated form of IgY, with evolutionary origins still unknown (OTA et al., 2003). This truncated IgY have low molecular weight $(\sim 120 \mathrm{kDa})$ and contain only two constant domains without two terminal domains of the heavy chain (TIZARD, 2002). This truncated isoform of $\operatorname{IgY}$ is produced as a result of alternative splicing of heavy chain messenger RNA, being called $\operatorname{IgY}(\Delta \mathrm{Fc})$. However, LI et al. (2012) have demonstrated that $\operatorname{IgY}$ and $\operatorname{IgY}(\Delta \mathrm{Fc})$ are codified in different genes in some species, like in the red-eared turtle. As the truncated isoform lacks a functional $\mathrm{Fc}$ region, it cannot undertake the usual immunoglobulin effector functions such as complement activation or Fc receptor binding (TIZARD, 2002). The immunoglobulin Y, full-sized and truncated, can be found in the same individual as in some ducks and geese, or only one form, like in Gallus domesticus where only the whole IgY is present (LIU \& HIGGINS, 1990; KITAGUCHI et al., 2008).

Previous studies have shown the presence of three immunoglobulin classes in birds (IgA, IgM and $\operatorname{IgY})$, but $\operatorname{IgY}$ is found in higher concentration ( 5 to $15 \mathrm{mg} / \mathrm{mL}$ ) than $\operatorname{IgM}$ ( 1 to $3 \mathrm{mg} / \mathrm{mL}$ ) and $\operatorname{IgA}$ ( 0.3 to $0.5 \mathrm{mg} / \mathrm{mL}$ ) in serum (ROSE et al., 1974; KOWALCZYK et al., 1985). As for mammals, the $\operatorname{IgM}$ is the predominant isotype produced in the avian primary humoral response while $\operatorname{IgY}$ is the predominant form in the secondary response (DAVISON et al., 2008).

Chicken IgY is predominantly systemic rather than a secretory antibody but can be also found in duodenal contents, tracheal washings and seminal plasma (LESLIE \& CLEM, 1969), besides the egg yolk. The IgY plays a similar biological role as mammalian $\mathrm{IgG}$, being considered the major immunoglobulin providing defense against infectious agents. Additionally, hatched chickens acquire an effective humoral immunity against common avian pathogens when absorb IgY from the egg yolk, until the complete maturation of the immune system (SCHADE et al., 2005).

\section{Transport of IgY from the serum to egg yolk}

There is a delay of five to six days since the appearance of $\operatorname{IgY}$ in serum until it is found in the yolk (DAVISON et al., 2008). The amount of IgY transferred across the follicular epithelium into the yolk is proportional to the $\mathrm{IgY}$ concentrations in serum (HAMAL et el., 2006). However, the concentration of IgY in egg yolk varies greatly between different bird species and even between chicken lines (CARLANDER, 2002). Yolk IgY concentrations were reported to be in the range of $7.9 \mathrm{mg} / \mathrm{ml}$ to $20-25 \mathrm{mg} /$ 
ml (ROSE et al., 1974; KOWALCZYK et al., 1985), depending on the analytical method used. About 100$200 \mathrm{mg}$ of total IgY can be extracted from a single egg with $2-10 \%$ being antigen specific (SCHADE et al., 1994; CARLANDER, 2002). IgM and IgA can reach concentrations of 0.15 and $0.7 \mathrm{mg} / \mathrm{ml}$ into the white eggs, respectively (ROSE et al., 1974). While low amounts of the IgM and IgA isotypes can be detected in the yolk, higher concentrations can be detected in the albumen (CARLANDER, 2002).

Studies performed in chickens have demonstrated that ovarian IgY incorporation happen through a specific receptor-mediated endocytosis and require the $\mathrm{Fc}$ region of the intact immunoglobulin for its binding and transport (KITAGUCHI et al., 2008). While both $\operatorname{IgY}$ and $\operatorname{IgY}(\Delta \mathrm{Fc})$ can be incorporated into the egg yolk, the full-length form (IgY) is preferentially incorporated (LIU \& HIGGINS, 1990). KITAGUCHI et al. (2008) speculate that IgY fragments lacking in the Fc region, Fab and $\mathrm{F}\left(\mathrm{ab}^{\prime}\right)_{2}$ fragments, can be incorporated by fluid-phase endocytosis without binding to the receptor or carrier protein after passing through the filtration gate.

IgY production

Chickens can be used for antibody production throughout their egg laying period. Different routes and various protocols have been reported so far but it is often difficult to compare the different methods described. For practical and economic reasons, chickens kept under field conditions are usually vaccinated intramuscularly in the breast muscle but subcutaneous immunization has also been used (SCHADE et al., 1996; CARLANDER et al., 2002). Injection of the antigen by intramuscular route frequently results in higher antibody levels by day $28^{\text {th }}$ after immunization (WOOLEY \& LANDON, 1995). Chickens immunized by the intramuscular route continue producing specific antibodies during more than 200 days or can be used for the entire laying period depending basically on the antibody titres induced (HORTON et al., 1984; SCHADE et al., 1996).

The total number of immunization required will depend upon the type and dose of the antigen, as well as on the particular adjuvant employed. Whether the antibody titres begin to decrease, booster immunizations can be applied during the laying period. A primary vaccination and a booster should be given preferentially before the laying period, with an interval of 6 weeks for emulsion-type adjuvants and 4 weeks for lipopeptide adjuvants (SCHADE et al., 1996).
According to SCHADE et al. (1996), conventional housing should be used for scientific purpose, when antibodies are used for therapeutic and human purposes the use of specific pathogens free chickens is compulsory. It is also possible to increase yolk antibody production by using a high producing chicken line and by genetic selection within the same line (CARLANDER, 2002).

Chicken IgY exhibits high avidity $\left(10^{9} \mathrm{~L} /\right.$ mol) even after the first immunization. In order to reach similar avidity values $\left(10^{10} \mathrm{~L} / \mathrm{mol}\right)$, a sheep, for example, must receive four boosters (WOOLEY \& LANDON, 1995). LARSSON et al. (1998), studied the immune response in chickens using small amounts of mammalian antigens, and observed a good immune response obtained with the use of 0.1 $1.0 \mu \mathrm{g}$ of bovine serum albumin. It was suggested that various concentrations of the antigen should be combined with the adjuvant. However, 25-100 $\mu$ g of antigen per immunization are usually used, although it is possible to obtain a good immune response with only $1 \mu \mathrm{g}$ per immunization (CARLANDER, 2002).

\section{Isolation and purification of IgY}

Currently, there are several methods of isolation and purification of functionally active chicken IgY from egg yolk described, even for largescale purification. Nevertheless, purity and yield vary greatly from method to method and require intense optimization for each experiment (CARLANDER, 2002). The choice of a specific method depends on the yield and purity desired, final application of the IgY as well as material cost, technology, labor skills and scale of extraction.

Formerly, widespread adoption of the use of IgY-based protocols have suffered from limitations due to existing IgY purification protocols, especially those concerning the high lipid content of egg yolk which is known to interfere with affinitybased purification steps (HANSEN et al., 1998). For this, all IgY purification methods require an initial delipidation step to extract insoluble lipids and lipoproteins (KO \& UHN, 2007; TAN et al., 2012) and then a subsequent step of separation. Among the currently accepted commercial and laboratory delipidation techniques, the most commonly used, involve either the use of water dilution under acidic conditions (AKITA \& NAKAI, 1993), chloroformPEG (POLSON, 1990), polyanionic polysaccharides such as xanthan (HATTA \& KIM, 1990), dextran sulphate or other natural gums such as pectin (JENSENIUS et al., 1981; CHANG et al., 2000), solvents such as acetone, detergents such as SDS 
(SRIRAM \& YGEESWARAN, 1999), carrageenan (HATTA \& KIM, 1990), aqueous 2-phase system with phosphate and triton X-100 (STALBERG \& LARSSON, 2001) or simple freeze and slow thaw cycling (SVENDSEN et al., 1995). These various IgY crude extraction methods give different results considering recovery and purity of levels obtained.

After the extraction step, three types of separation can be applied to eliminate the contaminants: precipitation with ammonium sulfate (KO \& UHN, 2007), or sodium sulfate (WOOLEY \& LANDON, 1995), or caprylic acid-ammonium sulfate (McLAREN et al., 1994), chromatography (HANSEN, 1998) and filtration (HERNÁNDEZCAMPOS et al. 2010). Several of these techniques could be included in one total clean-up procedure. Among these methods, AKITA \& NAKAI (1993) suggested the water dilution method under acidic conditions as the most efficient and economical procedure for large-scale production of IgY from egg yolk when compared with polyethylene glycol and dextran sulphate methods in terms of yield, purity and activity of IgY.

Ultrafiltration is one of the best methods of reduce the volume of egg yolk extract, and the efficacy of this methodology is greatly influenced by the presence of lipids or lipoproteins in the solution (KO \& UHN, 2007). Therefore, complete removal of lipids or lipoproteins from extract of egg yolk is required. Changes of $\mathrm{pH}$ value in egg yolk solution influence the extent of interactions between polysaccharides and proteins, the precipitation of polysaccharide-lipoprotein complexes, and the recovery of immunoactivity (SAMANT et al., 1993). CHANG et al. (2000) reported that addition of $0.1 \%$ of $\lambda$-carrageenan was effective in removing lipoproteins from the water extract of egg yolk at $\mathrm{pH}$ 5. TAN et al. (2012), have demonstrated an alternative methodology to isolate IgY from chicken egg yolks by using a mix of $\kappa$-carrageenan, pectin and $\mathrm{CaCl} 2$ as delipidation agent with use of ammonium sulphate $\left(\left(\mathrm{NH}_{4}\right)_{2} \mathrm{SO}_{4}\right)$ as an $\mathrm{IgY}$ precipitation reagent. This method also allowed the isolation of immunologically active IgY which can be used for further downstream immunotechnological processes.

Purity level of $\mathrm{IgY}$ from the ammonium sulfate method is higher than the cation exchange chromatography. The chromatography could handle only a small amount of samples, unlike the ammonium sulfate precipitation. Besides, the ammonium sulfate precipitation would be more efficient and useful purification method than cation exchange chromatography for the large-scale preparation of
IgY (KO \& UHN, 2007). After IgY precipitation by $\mathrm{NaCl}$, column chromatography (JENSENIUS et al., 1981) is frequently used in the final purification step. However, chromatography columns are generally expensive and impractical for the large-scale production of antibodies (KO \& UHN, 2007).

IgY in immunodiagnostic

Immunoglobulin $\mathrm{Y}$ has distinctive properties which can be exploited in various fields of research, diagnostics and therapy. Since the 1970 's, studies were performed in order to elucidate the functional and morphological characteristics of the poorly known immunoglobulin Y. Thereafter, there was an increase in the availability of research regarding IgY reagents (purification kits, standards, and labelled antibodies specifically against $\operatorname{IgY}$ ), and studies related with $\operatorname{IgY}$ production enabling the expansion of applications in immunodiagnostic techniques. In 1995, the production came to be called "IgY Technology" (WARR et al., 1995), which is the internationally accepted term for describing the production and use of this antibody. Furthermore, the "European Centre for the Validation of Alternative Methods" (ECVAM) strongly recommends that yolk antibodies should be used as an alternative to mammalian antibodies for the animal welfare (SCHADE et al., 1996).

The IgY can be harvested from the egg yolk instead of serum, thus making blood sampling obsolete. The antibody productivity of an egg-laying hen is greater than a similar sized mammal (HAU \& HENDRIKSEN, 2005) and the IgY concentration in the serum of adult hens can reach approximately $5-7 \mathrm{mg} / \mathrm{ml}$. As a laying hen produces approximately 20 eggs per month, over 2 grams of IgY can be isolated during this period corresponding approximately the IgY content of $300 \mathrm{ml}$ of serum or $600 \mathrm{ml}$ of blood. Only larger mammals can produce equal amounts of serum antibodies. Chicken antibodies, therefore, constitute a much less expensive vehicle for use in diagnostic purposes (CARLANDER, 2002).

The use of IgY can also be advantageous in immunological tests where the interference caused by $\mathrm{IgG}$ antibodies can be problematic, particularly, the sensitivity of the assay increases. One example is the rheumatoid factor (RF) that reacts with $\mathrm{IgG}$ from different mammalian species and also with mouse monoclonal antibodies (CARLANDER, 2002). RF is usually found in serum samples from patients with rheumatoid arthritis, but can also be found in patients with other diseases and even in 3-5\% of healthy individuals. Interference by anti-IgG antibodies and 
antibody-binding substances have been demonstrated in approximately $40 \%$ of serum samples from healthy individuals in an immunoradiometric assay (CARLANDER, 2002). Another fact is the increasing number of patients treated in vivo with mouse monoclonal antibodies. This treatment often evokes an antibody response in the patient resulting in production of human anti-mouse IgG antibodies (HAMA). HAMA may also be found in serum from patients who have not been treated with antibodies. The problem of RF and HAMA interference will increase as the sensitivity of the assay increases. Chicken IgY does not react with RF or HAMA and can be used to avoid interference due to these factors (LARSSON et al., 1992).

Chicken antibodies can also be used to reduce interference caused by mammalian complement activation in immunological assays. The complement cascade can be triggered after adding a fresh and undiluted serum sample to an assay, with subsequent binding of complement components to mammalian antibodies blocking the antigen-binding sites (LARSSON et al., 1992). The controls and standards used for immunological assays generally contain inactivated complement, whereas the complement activity in patient samples might differ, not only among patients but also between samples from the same patient. This difference in activity between the standards and the clinical samples might cause an analytical error (LARSSON et al., 1992; CARLANDER, 2002).

Whenever there is a risk of false positive results due to reactions between $\mathrm{Fc}$ region of mammalian antibodies and staphylococcal protein A or streptococcal protein $\mathrm{G}$, chicken antibodies could be a tool to circumvent these problems. Unlike IgG, IgY antibodies do not bind to bacterial Fc receptors, such as staphylococcal protein A or streptococcal protein G (JENSENIUS et al., 1981). However, one disadvantage is that neither protein A nor protein $\mathrm{G}$ can be used for the purification of chicken $\operatorname{IgY}$ (SCHADE et al., 1996).

Another important advantage arises from the phylogenetic distance and genetic background that distinguishes birds from mammals improving the likelihood that an immune response will be elicited against antigens or epitopes that may be nonimmunogenic in mammals (SPILLNER et al., 2012). Due to the evolutionary distance between chicken and mammalian immunoglobulins, IgY recognizes more epitopes when the immunogen used is a mammalian protein highly conserved. This feature can result in amplification of the signal, emphasizing the advantages of using $\operatorname{IgY}$ over $\operatorname{IgG}$ as the first antibody in some types of immunological reactions (CARLANDER, 2002). It is a well-known concept that a stronger immune response is elicited when the distance between the antigen source and the immune system increases. It has also been shown that chicken antibodies have 3-5 times more affinity to antibodies of pigs than the rabbit IgG for signal amplification in immunological test (HORTON et al., 1984; OLOVSSON \& LARSSON, 1993).

The limited flexibility of the avian $\operatorname{IgY}$ may account for the inability to precipitate antigens at physiological salt concentrations (WARR et al., $1995)$. IgY and $\operatorname{IgY}(\Delta \mathrm{Fc})$ both possess two antigenbinding sites and should, in principle, precipitate or agglutinate multivalent antigens but this does not always occur. Most chicken antibodies bind antigen strongly but display precipitating properties only at raised salt concentrations. Duck antibodies generally fail to exhibit efficient precipitation or agglutination reactions (HIGGINS et al., 1988). The nonprecipitating duck antibodies do not acquire the ability to precipitate antigen at raised salt concentrations (WARR et al., 1995).

More recently, chicken antibodies libraries have attracted scientific interest with increased reports on the isolation of chicken-derived antibody fragments. Such interest might, at least partially, be attributed to the genetic diversification which is achieved differently in chickens compared with the complexity of the mammalian mechanisms. In other words, avian species utilize a unique mode of DNA recombination, named gene conversion, resulting in a large and diverse antibody repertoire upon antigen priming (SPILLNER et al., 2012). This could be exemplified by the development of a humanized chicken monoclonal anti-IL12 antibody (NISHIBORI et al., 2006). It is also important to keep in mind that recombinant technologies currently available can generate monoclonal IgY or IgY-like antibodies from combinatorial libraries, sometimes without animal immunization (SPILLNER et al., 2012).

Taking together, all these characteristics clearly show substantial advantages of IgY technology in many medical areas, especially for diagnosis. Specific chicken antibodies have been successfully raised against a wide variety of antigens including proteins, peptides, lipid hormones and carbohydrate components from viruses, bacteria, fungi, plants and animals (SCHADE et al., 1994). Several studies have also shown promising results in the development of techniques for immunodiagnostic using IgY, such as immunoassays tests to detect circulating antigen 
of Schistosoma japonicum (CAI et al., 2012), development of IgY antibodies against proteins of Pythium insidiosum (RANGEL et al., 2010), use in antigen capture-ELISA (JULIARENA et al. 2007; VEERASAMI et al., 2008), among others.

\section{CONCLUSION}

IgY antibodies have many advantages over IgG antibodies such as strong avidity, scalable productivity, low assay background, and applicability to many immunoassays providing a strategy for improvement of assay performance and accuracy. Other advantageous features of IgY include a broader antigen-binding host range, absence of activation of the mammalian complement cascade and interaction with rheumatoid factors, or bacterial and human Fc receptors, certainly helping to reduce the costs of clinical and research immunological tests. Finally, the use of IgY represents an alternative method to utilization of mammal $\mathrm{IgG}$ and it is in agreement with international efforts, which aim to reduce or even replace animals in scientific experimentation not to mention other desirable characteristics and applications for immunodiagnostic.

\section{REFERENCES}

AKITA, E.M.; NAKAI, S. Production and purification of Fab' fragments from chicken egg yolk immunoglobulin Y (IgY). Journal of Immunological Methods, v.162, n.2, p.155-164, 1993. Available from: <http://www.sciencedirect.com/science/ article/pii/002217599390380P\#>. Accessed: May 28, 2013. doi: 10.1016/0022-1759(93)90380-P.

CAI, Y-C. et al. Chicken egg yolk antibodies (IgY) for detecting circulating antigens of Schistosoma japonicum. Parasitology International, v.61, n.3, p.385-390, 2012. Available from: $<$ http:// www.sciencedirect.com/science/article/pii/S1383576912000098>. Accessed: Dec. 2, 2012. doi: 10.1016/j.parint.2012.01.008.

CARLANDER, D. Avian IgY antibody: in vitro and in vivo. 2002. 53f. Phd Thesis - University of Uppsala, Faculty of Medecine (Sweden). Available from: <http://uu.diva-portal.org/smash/get/ diva2:161296/FULLTEXT01.pdf $>$. Accessed: May 28, 2013.

CHANG, H.M. et al. Isolation of immunoglobulin from egg yolk by anionic polysaccharides. Journal of Agriculture and Food Chemistry, v.48, p.995, 2000. Available from: <http://pubs.acs. org/doi/abs/10.1021/j9990539k>. Accessed: Dec. 2, 2012. doi: $10.1021 / \mathrm{j} f 990539 \mathrm{k}$

DAVISON, F. et al. Structure and evolution of avian immunoglobulins. In: DAVISON F. et al. Avian immunology. Amsterdan: Elsevier, 2008. Cap.6, p.107-127.

HANSEN, P. et al. Isolation and purification of immunoglobulins from chicken eggs using thiophilic interaction chromatography. Journal of Immunological Methods, v.215, n.1, p.1-7, 1998.
Available from: $<$ http://www.sciencedirect.com/science/article/pii/ S0022175998000507>. Accessed: May 28, 2013. doi: 10.1016/ S0022-1759(98)00050-7.

HAMAL, K.R. et al. Maternal antibody transfer from dams to their egg yolks, egg whites, and chicks in meat lines of chickens. Poultry Science, v.85, p.1364-1372, 2006. Available from: $<$ http:// ps.fass.org/content/85/8/1364.long>. Accessed: Dec. 2, 2012.

HATTA, H.; KIM, M. A novel isolation method for hen egg yolk antibody, "IgY". Agriculture and Biological Chemistry, v.54, p.2531-2535, 1990. Available from: <https://www.jstage.jst.go.jp/ article/bbb1961/54/10/54_10_2531/_article>. Accessed: Dec. 2, 2012. doi: $10.1271 / \mathrm{bbb} 1 \overline{9} 61 . \overline{5} 4.2531$.

HAU, J.; HENDRIKSEN, C.F.M. Refinement of polyclonal antibody production by combining oral immunization of chickens with harvest of antibodies from the egg yolk. Institute for Laboratory Research Journal, v.46, p.294-299, 2005. Available from: <http:// dels-old.nas.edu/ilar_n/ilarjournal/46_3/pdfs/v4603Hau.pdf $>$. Accessed: Dec. 2, $201 \overline{2}$.

HERNÁNDEZ-CAMPOS, S.J. et al. Purification of egg yolk immunoglobulin $(\mathrm{IgY})$ by ultrafiltration: effect of ph, ionic strength, and membrane properties. Journal of Agriculture and Food Chemistry, v.58, p.187-193, 2010. Available from: <http:// pubs.acs.org/doi/abs/10.1021/jf902964s>. Accessed: Dec. 2, 2012. doi: $10.1021 / \mathrm{jf} 902964 \mathrm{~s}$.

HIGGINS, D.A. et al. Bile immunoglobulin of the duck (Anas platyrhynchos). II. Antibody response in influenza A virus infections. Immunology, v.62, p.499-504, 1988. Available from: $<$ http://www.ncbi.nlm.nih.gov/pmc/articles/PMC1454141/>. Accessed: Dec. 2, 2012.

HORTON, J. et al. Exploitation of phylogenetic distance in cell surface immune labeling: studies with Beta - microglobulin. Journal of Investigative Dermatology, v.85, p.96-99, 1984. Available from: <http://www.nature.com/jid/journal/v84/n2/ abs/5614667a.html>. Accessed: Dec. 2, 2012. doi: 10.1111/15231747.ep12274979.

JENSENIUS, J.C. et al. Eggs: conveniently packaged antibodies. Methods for purification of yolk IgG. Journal of Immunological Methods, v.46, n.1, p.63-68, 1981. Available from: <http:// www.sciencedirect.com/science/article/pii/0022175981903331>. Accessed: Dec. 2, 2012. doi: 10.1016/0022-1759(81)90333-1.

JULIARENA, M. et al. Chicken antibodies: a useful tool for antigen capture ELISA to detect bovine leukaemia virus without crossreaction with other mammalian antibodies. Veterinary Research Communications, v.31, p.43-51, 2007. Available from: <http:// link.springer.com/article/10.1007\%2Fs 11259-006-3422-1>. Accessed: May 28, 2013. doi: 10.1007/s11259-006-3422-1.

KITAGUCHI, K. et al. Exclusion of polymeric immunoglobulins and selective immunoglobulin $\mathrm{Y}$ transport that recognizes its $\mathrm{Fc}$ region in avian ovarian follicles. Veterinary Immunology and Immunopathology, v.121, p.290-299, 2008. Available from: <http:// www.sciencedirect.com/science/article/pii/S0165242707003649>. Accessed: Dec. 2, 2012. doi: 10.1016/j.vetimm.2007.10.006.

KO, K.Y.; AHN, D.U. Preparation of immunoglobulin y from egg yolk using ammonium sulfate precipitation and ion exchange chromatography. Poultry Science, v.86, p.400-407, 2007. Available from: <http://poultsci.highwire.org/content/86/2/400. full.pdf + html $>$. Accessed: Dec. 2, 2012. 
KLEMPERER, F. Ueber natürliche immunität und ihre verwerthung für die immunisirungstherapie. Archiv für die Experimentelle Pathologie und Pharmakologie, v.31, p.356-382, 1893. Available from: <http://link.springer.com/ article/10.1007\%2FBF01832882>. Accessed: May 28, 2013.

KOWALCZYK, K. et al. Quantitation of maternal-fetal IgG transport in the chicken. Immunology, v.54, n.4, p.755-762, 1985. Available from: <http://www.ncbi.nlm.nih.gov/pmc/articles/ PMC1453552/pdf/immunology00197-0143.pdf $>$. Accessed: May, $28,2013$.

LARSSON, A. et al. Antibody response in laying hens with small amounts of antigen. Food and Agricultural Immunology, v.10, p.29-36, 1998. Available from: <http://www.tandfonline.com/doi/ abs/10.1080/09540109809354966\#preview>. Accessed: Dec. 2, 2012. doi: 10.1080/09540109809354966.

LARSSON, A. et al. Chicken antibodies: a tool to avoid interference by complement activation in ELISA. Journal of Immunological Methods, v.156, p.79-83, 1992. Available from: <http://www. sciencedirect.com/science/article/pii/002217599290013J $>$. Accessed: Dec. 2, 2012. doi: 10.1016/0022-1759(92)90013-J.

LESLIE, G.A.; CLEM, L.W. Phylogeny of immunoglobulin structure and function. III. Immunoglobulins of the chicken. Journal of Experimental Medicine, v.130, n.6, p.1337-1352, 1969. Available from: $<$ http://www.ncbi.nlm.nih.gov/pmc/articles/ PMC2138693/pdf/1337.pdf>. Accessed: May 28, 2013.

LI, L. et al. Extensive diversification of IgD-, IgY- and truncated $\operatorname{IgY}(\Delta \mathrm{Fc})$-encoding genes in the red-eared turtle (Trachemys scripta elegans). Journal of Immunology, v.189, n.8, p.39954004, 2012. Available from: <http://www.ncbi.nlm.nih.gov/ pubmed/22972932>. Acccessed: May 20, 2013. doi: 10.4049/ jimmunol.1200188.

LIU, S.S.; HIGGINS, D.A. Yolk-sac transmission and posthatching ontogeny of serum immunoglobulins in the duck (Anas platyrhynchos). Comparative Biochemistry and Physiology Part B: Biochemistry \& Molecular Biology, v.97, n.4, p.637-644, 1990. Available from: $<$ http://www.sciencedirect.com/science/article/ pii/0305049190901008> . Accessed: Dec. 2, 2012. doi: 10.1016/03050491(90)90100-8

McLAREN, R. D. et al. The use of caprylic acid for the extraction of the immunoglobulin fraction from egg yolk of chicken immunized with ovine $\alpha$-lactalbumin. Journal of Immunological Methods, v.177, p.175-184, 1994. Available from: <http:// www.sciencedirect.com/science/article/pii/0022175994901546>. Accessed: Dec. 2, 2012. doi: 10.1016/0022-1759(94)90154-6.

NISHIBORI, N. et al. Humanization of chicken monoclonal antibody using phage-display system. Molecular Immunology, v.43, p.634-642, 2006. Available from: <http://www.sciencedirect. com/science/article/pii/S0161589005001318>. Accessed: Dec. 2, 2012. doi: 10.1016/j.molimm.2005.04.002.

OLOVSSON, M.; LARSSON, A. Biotin labelling of chicken antibodies and their subsequent use in ELISA and immunohistochemistry. Comparative Immunology, Microbiology and Infectious Diseases, v.16, n.2, p.145-152, 1993. Available from: <http://www.sciencedirect.com/science/ article/pii/014795719390007R>. Accessed: Dec. 2, 2012. doi: 10.1016/0147-9571(93)90007-R.
OTA, T. et al. Lineage-restricted retention of a primitive immunoglobulin heavy chain isotype within the Dipnoi reveals an evolutionary paradox. Proceedings of the National Academy of Sciences of the United States of America, v.100, n.5, p.25012506, 2003. Available from: $<$ http://www.ncbi.nlm.nih.gov/pmc/ articles/PMC151370/>. Accessed: May, 28, 2013. doi: 10.1073/ pnas.0538029100.

POLSON, A. Isolation of IgY from the yolks of eggs by a chloroform polyethylene glycol procedure. Immunological Investigate, v.19, p.253, 1990. Available from: <http://informahealthcare.com/doi/ pdf/10.3109/08820139009041840>. Accessed: Dec. 2, 2012. doi: $10.3109 / 08820139009041840$.

RANGEL, M.F.N. et al. Development of IgY antibodies in chickens and IgG in rabbits immunized against proteins of Phytium insidiosum isolated from horses in the state of Rio de Janeiro. Pesquisa Veterinária Brasileira, v.30, n.1, p.87-93, 2010. Available from: $<$ http://www.scielo.br/scielo.php?script $=$ sci arttext\&pid=S0100-736X2010000100014>. Accessed: Dec. 2, 2012. doi: 10.1590/S0100-736X2010000100014.

ROSE, M.E. et al. Immunoglobulin classes in the hen's egg: their segregation in yolk and white. European Journal of Immunology, v.4, p.521-523, 1974. Available from: <http://onlinelibrary.wiley. com/doi/10.1002/eji.1830040715/pdf>. Accessed: Dec. 2, 2012. doi: $10.1002 /$ ji. 1830040715 .

SAMANT, S.K. et al. Protein-polysaccharide interaction: A new approach in food formulations. International Journal of Food Science and Technology, v.28, p.547-562, 1993. Available from: $<$ http://onlinelibrary.wiley.com/doi/10.1111/j.1365-2621.1993. tb01306.x/pdf $>$. Accessed: May 28, 2013. doi: 10.1111/j.13652621.1993.tb01306.x.

SCHADE, R. et al. Avian egg yolk antibodies. The egg laying capacity of hens following immunization with antigens of different kind and origin and the efficiency of egg yolk antibodies in comparison to mammalian antibodies. Alternativen zu Tierexperimenten. v.11, p.75-84, 1994. Available from: <http:// www.ncbi.nlm.nih.gov/pubmed/11178370\#>. Accessed: Dec. 2, 2012 .

SCHADE, R. et al. The production of Avian (Egg Yolk) Antibodies: IgY. Alternatives to Laboratory Animals, v.24, p.925-934, 1996. Available from: <http://ihcp.jrc.ec.europa.eu/our labs/eurlecvam/archive-publications/publication/WorkshopReport21.pdf>. Accessed: May 28, 2013

SCHADE, R. et al. Chicken egg yolk antibodies (IgY-technology): a review of progress in production and use in research and human and veterinary medicine. Alternatives to Laboratory Animals, v.33, p.129-154, 2005. Available from: <http://www.frame.org.uk/ atla_issue.php?iss_id=13>. Accessed: May 28, 2013.

SHIMIZU, M. et al. Molecular stability of chicken and rabbit immunoglobulin G. Bioscience, Biotechnology and Biochemistry, v.56 n.2, p.270-274, 1992. Available from: $<$ https:// www.jstage.jst.go.jp/article/bbb1992/56/2/56_2_270/_article>. Accessed: Dec. 2, 2012. doi: 10.1271/bbb.56.270.

SPILLNER, E. et al. Avian IgY antibodies and their recombinant equivalents in research, diagnostics and therapy. Biologicals, v.40, n.5, p.313-322, 2012. Available from: <http://www.sciencedirect. com/science/article/pii/S1045105612000759>. Accessed: Dec. 2, 2012. doi: 10.1016/j.biologicals.2012.05.003. 
SRIRAM, V.; YGEESWARAN, G. Improved recovery of immunoglobulin fraction from egg yolk of chicken immunized with AsialoGM1. Russian Journal of Immunology, v.4, p.131140, 1999. Available from: <http:/www.ncbi.nlm.nih.gov/ pubmed/12687120>. Accessed: Dec. 2, 2012.

STALBERG, J.; LARSSON, A. Extraction of IgY from egg yolk using a novel aqueous two-phase system and comparison with other extraction methods. Upsala Journal of Medical Sciences, v.106, p.99-110, 2001. Available from: <http:// informahealthcare.com/doi/pdf/10.3109/2000-1967-162>. Accessed: Dec. 2, 2012.

SVENDSEN, B.L. et al. Development and comparison of purification strategies for chicken antibodies from egg yolk. Laboratory Animal Science, v.45, n.1, p.89-93, 1995. Available from: <http://europepmc.org/abstract/MED/7752622>. Accessed: Dec. 2, 2012

TAN, S.H. et al. A novel, cost-effective and efficient chicken egg IgY purification procedure. Journal of Immunological Methods, v.380, n.1-2, p.73-76, 2012. Available from: <http:// www.sciencedirect.com/science/article/pii/S0022175912000804>. Accessed: Dec. 2, 2012. doi: 10.1016/j.jim.2012.03.003.
TIZARD, I. The avian antibody response. Seminars in Avian and Exotic Pet Medicine, v.11, n.1, p.2-14, 2002. Available from: $<$ http:// www.sciencedirect.com/science/article/pii/S1055937X0280010X>. Accessed: May 28, 2013. doi: 10.1053/saep.2002.28216.

VEERASAMI, M. et al. Serotyping of foot-and-mouth disease virus by antigen capture-ELISA using monoclonal antibodies and chicken IgY. New Microbiologica, v.31, p.549554, 2008. Available from: <http://www.ncbi.nlm.nih.gov/ pubmed/19123312>. Accessed: May 28, 2013.

WARR, G.W. et al. IgY: clues to the origins of modern antibodies. Immunology Today, v.16, n.8, p.392-398, 1995. Available from: <http:/www.sciencedirect.com/science/article/ pii/0167569995800085>. Accessed: May 28, 2013. doi: 10.1016/0167-5699(95)80008-5

WOOLEY, J.A.; LANDON, J. Comparison of antibody production to human interleukine-6 (I-L6) by sheep and chickens. Journal of Immunological Methods, v.178, p.253-265, 1995. Available from: <http://www.sciencedirect.com/science/ article/pii/002217599400263V >. Accessed: Dec. 2, 2012. doi: 10.1016/0022-1759(94)00263-V. 